\title{
Inventory analysis of the timber industry in Ghana
}

\author{
John Frank Eshun • José Potting • Rik Leemans
}

Received: 15 December 2009/Accepted: 2 June 2010 /Published online: 17 June 2010

(C) The Author(s) 2010. This article is published with open access at Springerlink.com

\begin{abstract}
Background, aim, and scope The timber sector, i.e., forestry and timber industry, plays an important role in the socioeconomic development of Ghana through timber products export. Timber production in this sector is associated with increasing environmental burdens in terms of use of materials and energy, production of emissions and waste, and land use changes. The purpose of this study was to compile a comprehensive life cycle inventory (LCI) to identify the most dominant environmental pressures for five major production lines in the timber industry, and to evaluate the influence of the choice of the functional unit on the results $\left(1 \mathrm{~m}^{3}, 1 \mathrm{~kg}\right.$, and 1 euro). LCA's of wood typically base their functional unit on volume, but mass or money may be more appropriate for the rather different products considered in this study.

Materials and methods The LCI covers five timber production lines, namely, air-dried lumber, kiln-dried lumber, plywood, veneer, and furniture parts. Three functional units were used for this study to identify the most appropriate basis for a fair comparison of the different timber products (functional units were $1 \mathrm{~m}^{3}, 1 \mathrm{~kg}$ and 1 euro). Questionnaires were administered to thirty selected companies in Ghana. These companies provided data about their material uses, energy requirements, and waste production for their operations from 2000 to 2007. The collected data were first converted into total annual average values, and next extrapolated to reflect the national average data for all 104 active companies. Finally, these data were
\end{abstract}

Responsible editor: Joerg Schweinle

J. F. Eshun $(\bowtie) \cdot J$. Potting $\cdot$ R. Leemans

Environmental Systems Analysis Group, Wageningen University,

PO Box 47, 6708PB Wageningen, The Netherlands

e-mail: John.Eshun@wur.nl expressed per functional unit for each of the five product lines on the basis of their production outputs (in volume, mass or money according to functional unit applied). Forest land used changes data was taken from the Ghana Timber Industry Development Division. Emissions for the several activities were taken from literature.

Results and discussion Land use change for timber production in Ghana between the estimated periods turned out to be $34.0 \times 10^{3}$ ha per year, which will lead to complete deforestation in the year 2023 if continued. The total energy consumed by the timber sector per year was estimated at $1.9 \times 10^{9}$ MJ per year. The results showed that $\mathrm{CO}_{2}$ emissions by the timber sector activities per year accounted for $745 \mathrm{k}$ tons per year and dominate overall greenhouse gases emissions in the timber sector (changes in carbons storage related to land use changes not included). Wood waste by the timber sector accounted for 0.8 million $\mathrm{m}^{3}$ per year. The enormous wastage of wood contributes enormously to the rapid depletion of the country's timber resources. The choice of the functional unit influences inventory results. The money-based functional unit, which also seems more appropriate for the different products considered, favors the value-added. Value-added products with strict sustainable forest management policy hold a promising future in terms of sustainability for the timber industry in Ghana.

Conclusions This study has yielded good quality primary data unique for LCA research in Africa. This will enhance LCA approaches in Ghana, and allows here identification of the main environmental pressures and their dominantly contributing processes in the timber sector. Land use changes due to forestry form a critical issue and require urgent attention. The chosen functional units' plays a crucial role in the environmental comparison of production line in the timber sector in Ghana. 
Recommendations and perspectives A comprehensive and transparent inventory for the timber industry provides the industry with an overview of areas in which material and thus economic savings can be made for the good of both environment and the industry finances. Good data keeping in the Ghanaian timber industry will help to build the required research capacity to develop local familiarity and competence in LCA techniques and applying these techniques will help to further certify tropical timber international markets.

Keywords Functional units · Ghanaian timber - Inventory analysis $\cdot$ Life cycle inventory $(\mathrm{LCI}) \cdot$ Tropical wood

\section{Background, aim, and scope}

The timber sector, i.e., forestry and timber industry, is important for Ghana because it provides jobs and incomes for numerous local communities, and significantly contributes to Ghana's foreign exchange earnings through timber products export. Since 1990 up to now, timber production is Ghana's fourth biggest foreign exchange earner (FOSA 2001, Lebedys 2004, Odoom 2008). In 2004, Ghana earned $€ 170$ million from 0.5 million $\mathrm{m}^{3}$ of wood product export (Oliver and Fripp 2005). Figure 1 gives an overview of main products and their share in total timber output. The timber production in this sector is associated with an increasing environmental burden in terms of use of resources, and production of emissions and waste (Ghana 2005a, b). Recently, the concern about environmental impacts has gone beyond relying on existing national regulation because international markets are increasingly demanding environmentally sound products.

Analyzing the environmental performance of the timber sector is complex because of a variety of environmental, political, social, and cultural dimensions. This requires a more integrated approach in identifying ways to access and reduce the total environmental burden of the timber sector. Life cycle thinking has become a key focus in environmental integrated product policy and an effective integration of life cycle thinking in the timber sector is considered as a critical success factor for more sustainable industrial models (Ometto et al. 2006, Swarr 2006, Huang et al. 2007, Sundkvist and Finnveden 2007, Lilja and Liukkonen 2008, Rau and OuYang 2008). Therefore, analyzing the environmental performance of the timber sector provides an effective first step to develop, implement and improve its environmental management.

Life cycle assessment (LCA) is a standardized method (ISO-14044 2006) to comprehensively assess and evaluate the complex environmental burdens associated with the manufacturing of a product from resource extraction to end of life (Berg 1997, Papatryphon et al. 2004, Milota et al. 2005, Puettmann and Wilson 2005, ISO-14044. 2006, Nebel et al. 2006, Swarr 2006, Matheys et al. 2007, Michelsen 2007, Rivela et al. 2007, Schweinle 2007, Werner and Nebel 2007). This method was used for assessing the environmental impact of the timber industry in Ghana and identifying effective environmental improvement options. This paper focuses on the first and second step in LCA that is often referred to as life cycle inventory (LCI). The LCI here covers the five major Ghanaian timber products: air-dried lumber, kiln-dried lumber, plywood, veneer, and furniture part. These products constitute about $90 \%$ of the total timber products export in Ghana.

Most existing LCA studies of the timber sector focused on a single production line, such as plywood production (Wilson and Sakimoto 2005), sawmill production (Milota et al. 2005), forestry, e.g. (Johnson et al. 2005, Lippke et al. 2005), veneer production (Wilson and Dancer 2005). The functional unit in these studies was usually defined as $1 \mathrm{~m}^{3}$ of product produced. This study focuses on a combination of production lines to achieve a higher level of integration of assessing environmental performance in the timber sector in Ghana. The products from these production lines obviously are different in the service they provide, and these different services are expected to be insufficiently expressed by the usual functional unit of $1 \mathrm{~m}^{3}$ of product produced. We therefore selected two additional functional units, one defined as $1 \mathrm{~kg}$ of product produced and the other as 1 euro of product produced (all products and functional units calculated at the same moisture content).

LCA has not received much attention from the research communities in Ghana. The method is still unknown, and data relevant for Ghana's timber sector are limited available. Most existing LCA studies for the timber sectors focus on plantation forestry as a source of raw material to the timber industry. This study focuses on natural tropical forests for resource extraction. It is important to note that LCI data on products from tropical timber is scares and limited in quality (Werner 2007). This study is therefore expected to generate LCI data for natural forestry in specific, and to provide an improved insight in the usefulness of the LCA tool for evaluating environmental policies in Ghana.

The objective of this study was to compile a comprehensive LCI to identify the most dominant environmental pressures in terms of material resource usage, emissions, energy use, waste production, and land use change, and to evaluate the influence of the choice of the functional unit for five major product lines in the timber sector in Ghana. The five major timber products are; air-dried lumber, kilndried lumber, plywood, veneer, and furniture parts.

This LCI study is intended for use amongst stakeholders and policy makers in deciding for the future of the timber 
Fig. 1 Share of wood products in total output of Ghana timber sector from 2000 to 2007 according to volume $\left(\mathrm{m}^{3}\right)$, mass (tons), and money $(€)$

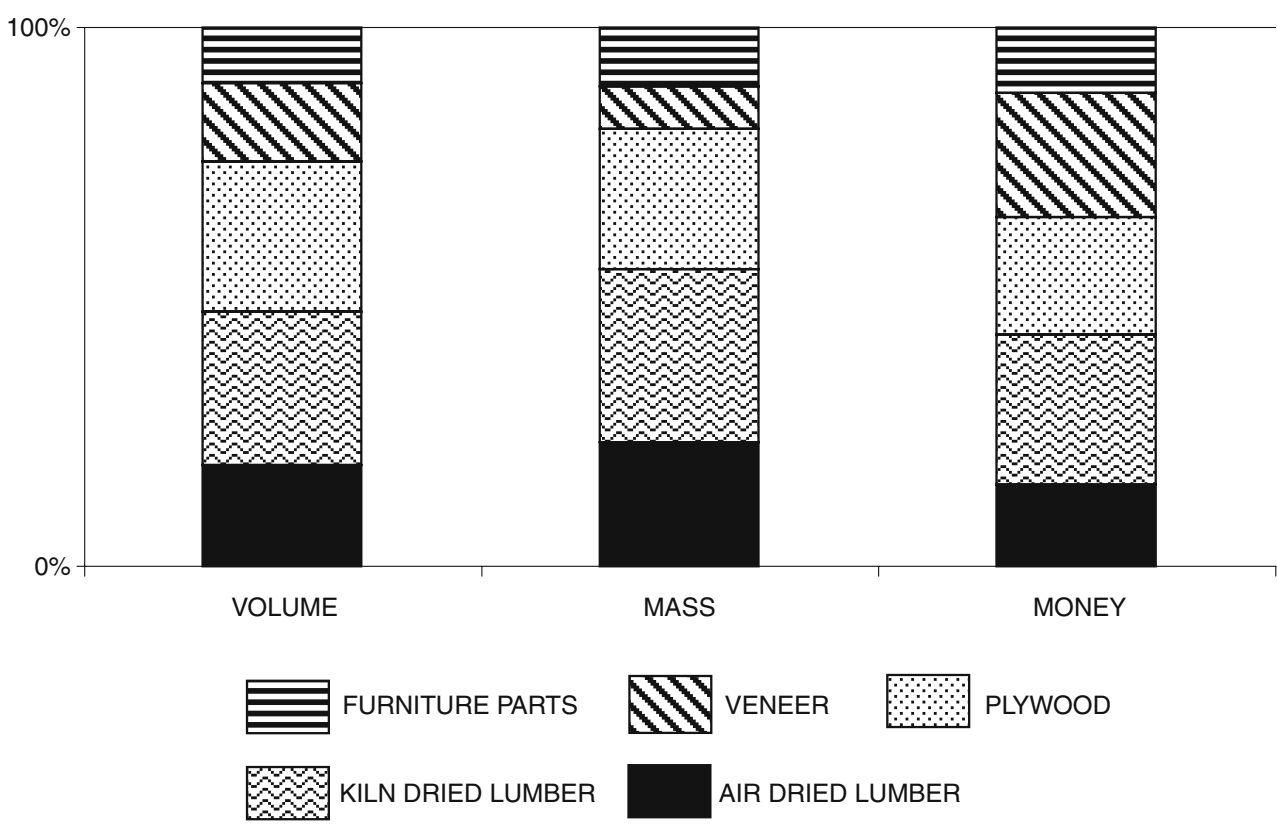

industry in Ghana. It is my hope that this study will contribute to enhance LCA use and research in Africa.

\section{Materials and methods}

\subsection{System description}

This study was carried out in accordance with ISO140442006 that specifies requirements and guidelines for conducting LCA. Figure 2 provides the process flow and system boundaries of timber sector in Ghana. It represents the linkages between subsystems, i.e., the forestry subsystem and the five product lines in the timber industry subsystem, and their unit-processes that together make up the product system or life cycle of products from Ghana's timber sector.

\subsection{Data collection procedure for forestry subsystem}

Natural tropical forest is the main source of timber supply to the timber industry in Ghana. It accounts for about $80 \%$ of the total input (Ghana 2005a, b). Forest plantation is now being developed in Ghana, but yet of relatively minor importance for Ghana's timber sector, and therefore not included in the LCI. The main activities in forestry (logging) subsystem are represented in Fig. 2. LCI for these activities focused on the material use, energy use, emissions of pollutants, and land use changes. Except for land use, data collection for these forestry activities was taken together with data collection for the timber industry. That is, because all timber companies in Ghana have forestry department attached to them that deal with all forestry issues related to the input to their own company activities. The forest land used changes data source was taken from Ghana Timber Industry Development Division (2006). Land degradation by deforestation and desertification is a major problem caused by the timber sector.

\subsection{Data collection for timber industry subsystem}

A selection of 30 timber companies was made of one hundred and four (104) active timber companies in Ghana. Two sampling techniques were adopted. The first statestratified sampling was based on three market orientations of companies. According to Forestry Product Inspection Bureau (1996), the market orientations of the thirty (30) selected companies consist of fifteen (15) companies providing 100\% export market, eight (8) companies 100\% domestic market, and seven (7) companies mixed (Table 1). The second state-stratified sampling was based on the log input category of the companies. The total of thirty (30) selected companies consists of twelve (12) small, eight (8) medium, six (6) large and four (4) extra-large ones. Each company covers one product line only. This means that companies with more than one product line were excluded from the sample. This was done to enhance data processing.

Regional distribution of companies was a consideration for the selection of samples for the study. Questionnaires were administered to the thirty (30) selected companies in Ghana and they provided data about the inputs and outputs to their activities for resources, material uses, energy requirements, and waste production from 2000 to 2007.

Records keeping in Ghana do provide data in lump, and thus not according to unit-processes in the forestry subsystem and for the sawmilling and ply-milling and 
Fig. 2 Flow chart of the unitprocesses in the forestry and timber industry subsystems of the timber sector in Ghana
Natural tropical forest

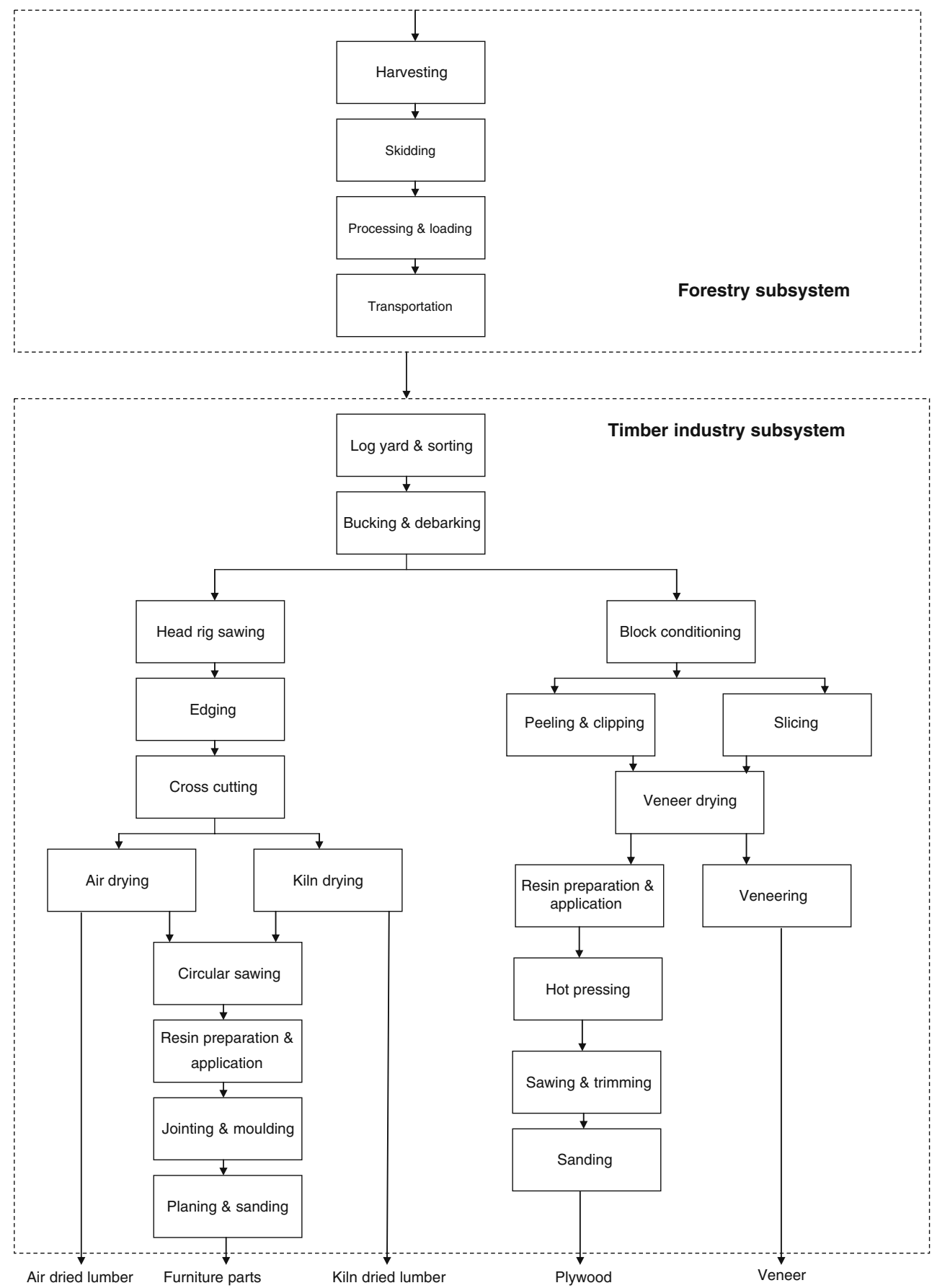

furniture processes in the timber industry subsystem (see Fig. 2). These lumped data were allocated to the five product lines on the basis of the production outputs (in volume, mass, or money according to functional unit applied). Process-specific data were provided for the kiln drier and for resin preparation and application. The data of five companies were considered of insufficient quality. The collected data for the other twenty five (25) companies were converted into total annual average values, and for a fair comparison on the national level extrapolated to reflect the national average data for all one hundred and four (104) active companies. The sawdust, off cuts, and barks are treated as wood waste in the Ghanaian timber industry unless they are used for fuelling in-house boilers. No allocation rules were needed since the companies were selected to cover one product line only and therefore the level of process detail was sufficient to avoid multiple output processes. 
Table 1 Sampling scheme of 30 selected companies used for data collection in the timber sector in Ghana

\begin{tabular}{|c|c|c|c|c|}
\hline \multirow[t]{2}{*}{ Log input-volume criteria } & \multicolumn{4}{|c|}{ Market orientation criteria } \\
\hline & $100 \%$ Export & Mixed $(50-50 \%)$ & $100 \%$ Domestic & Total \\
\hline $\begin{array}{l}\text { Small } \\
\qquad \mathrm{V}<7,000 \mathrm{~m}^{3} \text { per annum }\end{array}$ & 5 & 4 & 3 & 12 \\
\hline $\begin{array}{l}\text { Medium } \\
7,500<\mathrm{V}<20,000 \mathrm{~m}^{3} \text { per }\end{array}$ & 4 & 2 & 2 & 8 \\
\hline $\begin{array}{l}\text { Large } \\
20,000<\mathrm{V}<40,000 \mathrm{~m}^{3} \text { pe }\end{array}$ & um & 2 & 2 & 6 \\
\hline $\begin{array}{l}\text { Extra large } \\
\mathrm{V}>40,000 \mathrm{~m}^{3} \text { per annum }\end{array}$ & 4 & 0 & 0 & 4 \\
\hline Total & 15 & 8 & 7 & 30 \\
\hline
\end{tabular}

Data relevant for Ghana's timber sector were limited available. Additional interviews were done to check data quality and to ascertain which processes were specifically covered by lumped data. Some assumptions had to be made. For instance, the average distance between the forest sites and the wood production companies was taken to be $500 \mathrm{~km}$ (in reality the distance varies from 200 to $500 \mathrm{~km}$ ).

\subsection{Calculation of emissions in the timber sector}

Emission inventory data were not available for the timber companies visited in Ghana. We used the emission factors in Table 2 to calculate selected emissions as function of production volumes of a particular product line as illustrated in Eq. 1. We made the resulting emissions as local as possible by calculating them as function of production volumes as provided by the survey (see Table 4). In this context, the production capacities were virtually thought of as an activity (Jawjit et al. 2006). This study took into account emissions contributing to global warming, acidification, smog, and human toxicity. The selected emissions are $\mathrm{CO}_{2}, \mathrm{CH}_{4}$, and $\mathrm{N}_{2} \mathrm{O}$ for global warming; $\mathrm{SO}_{2}$ and $\mathrm{NO}_{X}$ for acidification; $\mathrm{CH}_{4}, \mathrm{NO}_{X}, \mathrm{NMVOC}, \mathrm{CO}$ for smog; $\mathrm{NO}_{X}$ and $\mathrm{SO}_{2}$ for human toxicity. The results of emission calculations were expressed in ton of pollutant either emitted or generated from a product line of the timber sector per year (ton per year) as illustrated in Table 5.

Emission $=$ Activity $\times$ Emission Factor

\subsection{Functional unit}

Volume is commonly used as output unit in timber companies, and the functional unit for LCAs of timber products is usually accordingly defined as $1 \mathrm{~m}^{3}$ of product produced (Milota et al. 2005, Wilson and Sakimoto 2005).

A functional unit provides the reference to which the environmental inputs and outputs of a product system are related ISO-14044 (2006). It defines the service of the studied products in relation to user requirements and is typically expressed as the unit service for a specified period of time. The functional unit must include both a qualitative and quantitative description of the products service provided to the user so that the product can be compared on a fair basis. Such functional unit is difficult to define here as the properties and services differ significantly between the wood product lines covered in this study. A generic functional unit is nevertheless necessary for comparability of LCA results. The different services are expected to be insufficiently expressed by the usual functional unit of $1 \mathrm{~m}^{3}$ of product produced. We therefore selected two additional functional units. One defined as $1 \mathrm{~kg}$ of product produced and the other as 1 euro of product produced. The results for all functional units and products are expressed at the same moisture content of $12 \%$. The inventory results for the five timber products in this study were thus compared on a $\mathrm{kg}$ ton $^{-1}$, $\mathrm{kg} \mathrm{m}^{-3}$ and $\mathrm{kg} €^{-1}$ output basis.

\section{Results and discussion}

The results of the inventory study were first extrapolated to total inputs and outputs of the Ghanaian timber sector to also have a basis for fair comparison on the national level. Next, they were analyzed in accordance to the selected three functional units for a fair comparison at the product level (i.e., environmental inputs and outputs expressed per volume, mass and money unit of timber product). Results are calculated for each of the five different product lines of the timber sector in Ghana (air-dried lumber, kiln-dried lumber, plywood, veneer, and furniture parts).

\subsection{Forestry subsystem-land use inventory}

Inventory results for material and energy use are presented in the next section as these were taken together with the timber industry subsystem. This section focuses on land use 
Table 2 Emission factors as used in Eq. 1 for the calculation of the emissions from timber sector in Ghana

\begin{tabular}{|c|c|c|c|c|}
\hline Activity area & $\begin{array}{l}\text { Compound } \\
\text { emitted }\end{array}$ & $\begin{array}{l}\text { Emission } \\
\text { factors }\end{array}$ & Unit & Reference \\
\hline \multicolumn{5}{|l|}{ Forestry subsystem } \\
\hline \multirow[t]{7}{*}{$\begin{array}{l}\text { Harvesting activities and transportation of log to company } \\
\text { (diesel used) }\end{array}$} & $\mathrm{CO}_{2}$ & 3150.00 & $\mathrm{~g} / \mathrm{kg}$ fuel & $\begin{array}{l}\text { Schwaiger and Zimmer } \\
\text { (1995) }\end{array}$ \\
\hline & $\mathrm{CO}$ & 15.00 & $\mathrm{~g} / \mathrm{kg}$ fuel & IPCC (1997) \\
\hline & $\mathrm{N}_{2} \mathrm{O}$ & 0.02 & $\mathrm{~g} / \mathrm{kg}$ fuel & $\begin{array}{l}\text { Schwaiger and Zimmer } \\
\text { (1995) }\end{array}$ \\
\hline & $\mathrm{CH}_{4}$ & 6.91 & $\mathrm{~g} / \mathrm{kg}$ fuel & $\begin{array}{l}\text { Schwaiger and Zimmer } \\
\text { (1995) }\end{array}$ \\
\hline & $\mathrm{NO}_{\mathrm{X}}$ & 50.00 & $\mathrm{~g} / \mathrm{kg}$ fuel & IPCC (1997) \\
\hline & NMVOC & 6.50 & $\mathrm{~g} / \mathrm{kg}$ fuel & IPCC (1997) \\
\hline & $\mathrm{SO}_{2}$ & 20.00 & $\mathrm{~g} / \mathrm{kg}$ fuel & IPCC (1997) \\
\hline \multicolumn{5}{|l|}{ Timber industry subsystem } \\
\hline \multirow[t]{5}{*}{ Saw milling drying of wood } & $\mathrm{CO}_{2}$ & 920.00 & $\begin{array}{l}\mathrm{kg} / \mathrm{m}^{3} \text { of } \\
\text { wood }\end{array}$ & USEPA (2003) \\
\hline & $\mathrm{CO}$ & 2.55 & $\begin{array}{l}\mathrm{kg} / \mathrm{m}^{3} \text { of } \\
\text { wood }\end{array}$ & USEPA (2003) \\
\hline & VOC & 1.65 & $\mathrm{~kg} / \mathrm{m}^{3}$ of & USEPA (2003) \\
\hline & $\mathrm{SO}_{2}$ & 0.12 & $\begin{array}{l}\mathrm{kg} / \mathrm{m}^{3} \text { of } \\
\text { wood }\end{array}$ & USEPA (2003) \\
\hline & $\mathrm{NO}_{\mathrm{X}}$ & 2.55 & $\begin{array}{l}\mathrm{kg} / \mathrm{m}^{3} \text { of } \\
\text { wood }\end{array}$ & USEPA (2003) \\
\hline \multirow[t]{6}{*}{ Boiler activities Biomass combustion } & $\mathrm{CO}_{2}$ & 110.00 & ton/TJ & IPCC (1997) \\
\hline & $\mathrm{CO}$ & 4000.00 & $\mathrm{~kg} / \mathrm{TJ}$ & IPCC (1997) \\
\hline & $\mathrm{CH}_{4}$ & 30.00 & $\mathrm{~kg} / \mathrm{TJ}$ & IPCC (1997) \\
\hline & $\mathrm{N}_{2} \mathrm{O}$ & 4.00 & $\mathrm{~kg} / \mathrm{TJ}$ & IPCC (1997) \\
\hline & NMVOC & 250.00 & $\mathrm{~kg} / \mathrm{TJ}$ & IPCC (1997) \\
\hline & $\mathrm{NO}_{\mathrm{X}}$ & 100.00 & $\mathrm{~kg} / \mathrm{TJ}$ & IPCC (1997) \\
\hline \multirow[t]{5}{*}{ Veneer drying } & $\mathrm{CO}_{2}$ & 920.00 & $\begin{array}{l}\mathrm{kg} / \mathrm{m}^{3} \text { of } \\
\text { wood }\end{array}$ & USEPA (2003) \\
\hline & $\mathrm{CO}$ & 2.55 & $\begin{array}{l}\mathrm{kg} / \mathrm{m}^{3} \text { of } \\
\text { wood }\end{array}$ & USEPA (2003) \\
\hline & VOC & 1.65 & $\begin{array}{l}\mathrm{kg} / \mathrm{m}^{3} \text { of } \\
\text { wood }\end{array}$ & USEPA (2003) \\
\hline & $\mathrm{SO}_{2}$ & 0.03 & $\mathrm{~kg} / \mathrm{m}^{3}$ of & USEPA (2003) \\
\hline & $\mathrm{NO}_{\mathrm{X}}$ & 0.12 & $\begin{array}{l}\mathrm{kg} / \mathrm{m}^{3} \text { of } \\
\text { wood }\end{array}$ & USEPA (2003) \\
\hline \multirow[t]{7}{*}{ Diesel used } & $\mathrm{CO}_{2}$ & 3150.00 & $\mathrm{~g} / \mathrm{kg}$ fuel & $\begin{array}{l}\text { Schwaiger and Zimmer } \\
\text { (1995) }\end{array}$ \\
\hline & $\mathrm{CO}$ & 15.00 & $\mathrm{~g} / \mathrm{kg}$ fuel & IPCC (1997) \\
\hline & $\mathrm{N}_{2} \mathrm{O}$ & 0.02 & $\mathrm{~g} / \mathrm{kg}$ fuel & $\begin{array}{l}\text { Schwaiger and Zimmer } \\
\text { (1995) }\end{array}$ \\
\hline & $\mathrm{CH}_{4}$ & 6.91 & $\mathrm{~g} / \mathrm{kg}$ fuel & $\begin{array}{l}\text { Schwaiger and Zimmer } \\
\text { (1995) }\end{array}$ \\
\hline & $\mathrm{NO}_{\mathrm{X}}$ & 50.00 & $\mathrm{~g} / \mathrm{kg}$ fuel & IPCC (1997) \\
\hline & NMVOC & 6.50 & $\mathrm{~g} / \mathrm{kg}$ fuel & IPCC (1997) \\
\hline & $\mathrm{SO}_{2}$ & 20.00 & $\mathrm{~g} / \mathrm{kg}$ fuel & IPCC (1997) \\
\hline
\end{tabular}

changes. The natural forest for timber production between 1989 and 2002 decreased according to official numbers by $442.0 \times 10^{3}$ ha as illustrated in Table 3 . This gives a yearly degradation of $34.0 \times 10^{3}$ ha. If this degradation trend continues in the same speed, then the total production area will be reduced to $515.0 \times 10^{3}$ ha by the end of 2008. All the forest will have been gone by the year 2023 . 
Table 3 Land use inventory of natural forest for timber production from 1989 to 2002 in Ghana

\begin{tabular}{lcccc}
\hline Region & Total reserve area $\left(10^{3}\right.$ ha $)$ & $\begin{array}{l}\text { Production forest }\left(10^{3} \text { ha }\right), \\
1989\end{array}$ & $\begin{array}{l}\text { Production forest }\left(10^{3} \text { ha }\right), \\
2002\end{array}$ & $\begin{array}{l}\text { Production forest }\left(10^{3} \text { ha/ }\right. \\
\text { yr })\end{array}$ \\
\hline Ashanti & 384 & 235 & 126 & 8 \\
Brong & 264 & 202 & 73 & 6 \\
Ahafo & 111 & 123 & 70 & 4 \\
Central & 154 & 88 & 323 & 1 \\
Eastern & 701 & 513 & 719 & 34 \\
Western & 1,613 & 1,161 & & 15 \\
Total & & &
\end{tabular}

Source: (TIDD 2006)

The World Bank (2006) estimates Ghana's deforestation in 2003 at around $65.0 \times 10^{3}$ ha per year. This equals with an annual cost of degradation of around $3.5 \%$ of Ghana's Gross Domestic Product, together with habitat loss, species extirpation. Deforestation value according to World Bank is almost doubling the deforestation value used in this study, because the World Bank (2006) also includes illegal logging and mining activities in some forest reserves. Degradation of the forest resource is taking place for both off- and on-forest reserve. Off-forest reserve refers to unmanaged forest, where loss has arisen from the mix of expansion of farming (especially cocoa) and illegal demand of timber for informal timber sector industry. On-forest reserve refers to managed forest, where degradation has also accelerated dramatically in the last decade, due to overlogging, encroachment, illegal logging, and bushfires. This study refers to the formal timber sector.

\subsection{Timber industry-materials, energy, and waste}

The survey resulted in quantification of the combined use of materials and energy in the forestry and the timber industry (Table 4). The production and utilization of round wood between 2000 to 2007 was approximately 1.3 million $\mathrm{m}^{3}$ of $\log$ s as input to, and approximately 0.6 million $\mathrm{m}^{3}$ of timber products as output from the timber industry annually (see Table 4). Kiln-dried lumber and air-dried lumber production lines contributed with 0.5 million $\mathrm{m}^{3}$ per year to enormous amount of wood waste in the timber sector. This is as a result of the low production recovery in the Ghanaian timber industry. Another notable source of wood waste occurs in the forest during timber harvesting. This wood waste is usually not recorded. The enormous quantities of waste per product line in Table 4 are therefore even an underestimate of the actual quantity of wood wasted in Ghana's timber sector.

One factor that is contributing enormously to the rapid depletion of the country's timber resources is wastage of wood during log processing in industry. As a consequence, the timber industry in Ghana produces a considerable amount of wood waste, in total estimated to be in the order of 0.8 million $\mathrm{m}^{3}$ per year (excluding the above-mentioned forest contribution from harvesting waste) as illustrated in Table 4. Wood waste thus constitutes a major setback to the sustainable management of the timber sector. Both avoidable and unavoidable wood wastes generated during harvesting and conversions are enormous. When pooled together, however, it can be used in the production of downstream processes such as wood-based panel manufacturing in Ghana. This is regrettably not common practice in Ghana right now.

According to the energy inventory data in Table 4, the total energy consumed by the timber sector per year is estimated at $1.9 \times 10^{9} \mathrm{MJ}$ per year. The main energy use was for drying wood products and is provided by combustion of in-house production waste in steam production boiler (no allocation rules were needed since the companies where selected to cover one product line only). This accounts for about $80 \%$ of the total energy consumed. The second energy users are the timber harvesting and transportation operations. Considering the energy usage by the various wood production lines, plywood production was the highest energy consuming process followed by the kiln-dried lumber.

\subsection{Emission inventory of the timber sector in Ghana}

Table 5 gives a summary of results for the greenhouse gases emission inventory of the timber industry in Ghana. This study shows that $\mathrm{CO}_{2}$ emissions in the timber sector accounted for $745 \mathrm{k}$ tons per year. This quantity dominates overall greenhouse gases emissions in timber sector. One might come to the thought that the emission of $\mathrm{CO}_{2}$ from biomass combustion can be excluded from the greenhouse gas inventories, since this $\mathrm{CO}_{2}$ is compensated through its fixation in the combusted wood derived from trees. IPCC (2006) recommends in the case of tropical forest, however, to specifically flag these emissions as an indicator for deforestation. Kiln-dried lumber, plywood, and veneer product lines contributed mostly to the $\mathrm{CO}_{2}$ emissions. 
Table 4 Average survey results for material and energy consumption, and waste production from 2000 to 2007 extrapolated to the average national yearly production of the timber sector in Ghana

\begin{tabular}{|c|c|c|c|c|c|c|c|}
\hline & Units & Air-dried lumber & Kiln-dried lumber & Plywood & Veneer & Furniture parts & Total \\
\hline \multicolumn{8}{|l|}{ Material input } \\
\hline Logs & $\mathrm{mln} \mathrm{m}^{3} /$ year & 0.32 & 0.44 & 0.32 & 0.12 & 0.09 & 1.29 \\
\hline Urea formaldehyde & $\mathrm{mln} \mathrm{m}^{3} /$ year & 0.00 & 0.00 & 0.05 & 0.00 & 0.03 & 0.08 \\
\hline \multicolumn{8}{|l|}{ Energy input } \\
\hline Diesel (Timber harvest) & $\mathrm{mln} \mathrm{MJ} / \mathrm{yr}$ & 20.00 & 29.00 & 19.00 & 7.00 & 10.00 & 85.00 \\
\hline Diesel (Transport) & $\mathrm{mln} \mathrm{MJ} / \mathrm{yr}$ & 21.00 & 28.00 & 8.00 & 5.00 & 4.00 & 67.00 \\
\hline Electricity (Hydropower) & $\mathrm{mln} \mathrm{MJ} / \mathrm{yr}$ & 19.00 & 26.00 & 19.00 & 7.00 & 5.00 & 76.00 \\
\hline Steam generation from boiler & $\mathrm{mln} \mathrm{MJ} / \mathrm{yr}$ & 0.00 & 322.00 & 335.00 & 176.00 & 114.00 & 947.00 \\
\hline Biomass combustion & $\mathrm{mln} \mathrm{MJ} / \mathrm{yr}$ & 0.00 & 249.00 & 291.00 & 148.00 & 89.00 & 775.00 \\
\hline Total & $\mathrm{mln} \mathrm{MJ} / \mathrm{yr}$ & 60.00 & 654.00 & 672.00 & 343.00 & 222.00 & $1,950.00$ \\
\hline \multicolumn{8}{|l|}{ Material and waste output } \\
\hline Wood product & $\mathrm{mln} \mathrm{m}^{3} /$ year & 0.11 & 0.16 & 0.16 & 0.09 & 0.06 & 0.58 \\
\hline Sawdust & $\mathrm{mln} \mathrm{m}^{3} /$ year & 0.02 & 0.02 & 0.02 & 0.01 & 0.01 & 0.08 \\
\hline Off cuts & $\mathrm{mln} \mathrm{m}^{3} /$ year & 0.16 & 0.22 & 0.08 & 0.01 & 0.04 & 0.51 \\
\hline Barks & $\mathrm{mln} \mathrm{m}^{3} /$ year & 0.03 & 0.04 & 0.03 & 0.01 & 0.01 & 0.12 \\
\hline Peeler core & $\mathrm{mln} \mathrm{m}^{3} /$ year & 0.00 & 0.00 & 0.08 & 0.01 & 0.00 & 0.09 \\
\hline Total & $\mathrm{mln} \mathrm{m}^{3} /$ year & 0.32 & 0.44 & 0.37 & 0.12 & 0.12 & 1.37 \\
\hline
\end{tabular}

Not included in this study are $\mathrm{CO}_{2}$ emissions from changes in carbons storage related to land use changes, e.g., emission from forest slashes, changes in below-ground biomass and organic carbon in soil. This is worth considering in future research work in Ghana.

\subsection{Comparison of functional units}

For a fair comparison of different products, LCA data should be expressed in terms of a functional unit that appropriately describes the function of the product or process being studied. Careful selection of the functional unit to measure and display the LCA results will improve the validity of the study and the usefulness of the results. The different services provided by the five products in our study hamper the selection of one common functional unit suitably covering this. We therefore choose to express results in terms of volume, mass, and monetary functional units. Figure 1 already showed that the share of the five major products in total output of Ghana's timber sector depends on the choice of units. Money, especially, clearly influences the share of veneer in total product output. Figure 3 shows that the choice of functional units also influences inventory results. The energy use, wood waste generation, emission, and land use changes varies between the three chosen units for each of the five product lines. These differences come from the fact that the three functional units represent different product parameters that each only partly reflect the different services provided by each of the five products to the user. Relevance of product parameters can thus influence the choice of one specific functional unit for a particular product (Kluppel 1998, Erlandsson and Borg 2003, Matheys et al. 2007). Whereas veneer has the largest share in total financial output (see Fig. 1), its inventory data makes the smallest contribution if expressed per money units.

The influence of the three functional units on the results are quantified in Table 6, and graphically represented in Fig. 3. Comparing the results shows that the money-based functional unit favors the value-added products and veneer in particular. This in turn favors downstream processing of wood. Downstream processing of wood has the tendency with strict sustainable forest management policy to slow down the rate of exploitation of timber (ITTO 2005). High value products with strict sustainable forest management policy thus hold the potential to slow down the pressure on tropical forest, and this holds a promising future in terms of sustainability for the timber sector in Ghana.

\section{Conclusions}

LCI data for Ghana's timber industry were as to yet limitedly available. This study has yielded good quality primary data unique for LCA research in Africa. Only emissions were not available as primary data and therefore largely based on literature. All data used in this study was considered to be the best available data. Despite the fact that we did not perform a formal sensitivity analysis, the data obtained in this LCI clearly shows the difference 
Table 5 Results for emission inventory by products of the timber sector in Ghana (averaged over 2000 to 2007)

\begin{tabular}{|c|c|c|c|c|c|c|c|}
\hline Products & $\begin{array}{l}\mathrm{CO}_{2} \\
\text { ktons/year }\end{array}$ & $\begin{array}{l}\mathrm{CH}_{4} \\
\text { tons/year }\end{array}$ & $\begin{array}{l}\mathrm{N}_{2} \mathrm{O} \\
\text { tons/year }\end{array}$ & $\begin{array}{l}\mathrm{SO}_{2} \\
\text { tons/year }\end{array}$ & $\begin{array}{l}\mathrm{NO}_{\mathrm{X}} \\
\text { tons/year }\end{array}$ & $\begin{array}{l}\text { NMVOC } \\
\text { tons/year }\end{array}$ & $\begin{array}{l}\mathrm{CO} \\
\text { ktons/year }\end{array}$ \\
\hline Air-dried lumber & 8 & 3 & 0 & 53 & 165 & 128 & 0 \\
\hline Kiln-dried lumber & 219 & 263 & 10 & 76 & 451 & 286 & 9 \\
\hline Plywood & 223 & 147 & 8 & 50 & 366 & 173 & 9 \\
\hline Veneer & 219 & 76 & 5 & 18 & 171 & 84 & 5 \\
\hline Furniture parts & 77 & 25 & 3 & 25 & 148 & 62 & 3 \\
\hline Total & 745 & 514 & 26 & 222 & 1,301 & 733 & 26 \\
\hline
\end{tabular}

between the product lines and therefore serve the purpose of the study.

The main environmental pressures and their dominantly contributing processes have been identified in Ghana's timber sector (i.e., in its forestry subsystem and timber industry subsystem). It was found that enormous amounts of wood wastes are generated in the timber industry due to its low timber production recovery. Wastage of wood during timber processing in the timber industry therefore contributes enormously to the rapid depletion of the country's timber resources. $\mathrm{CO}_{2}$ emissions were identified to dominate overall greenhouse gases emissions. Main contributors here are the kiln-dried lumber, plywood, and veneer production lines (changes in carbons storage related to land use changes were not included). Biomass combustion in steam production boiler, which was mainly used for drying wood products, accounted for the highest energy usage. Timber harvesting and transportation operations were the second largest energy users in the sector as a result of long timber transport distances. Land use changes were identified as a critical issue and require an urgent attention. If the degradation trend continues in the same speed, then the total forest production area would be gone by the year 2023 .

The result of this study should preferably not be influenced significantly by the choice of one out of the three relevant functional units (Kluppel 1998). The chosen functional units' shows to play a crucial role, however, in the environmental comparison of production lines in the timber sector in Ghana. Money, especially, has a clear influence, particularly on the results for the veneer product line. Veneer has the largest share in total financial output and makes the smallest contribution per money units.

The enormous wood wastage and land use changes in particular constitute a setback to the sustainable management of timber sector. Natural tropical forest resources are limited and the introduction of necessary constraints under sustainable forest management practices further reduces the availability of timber for harvesting. To meet the anticipated needs of the timber industry, greater emphasis must be placed on value-added production. It is therefore critical to substantially raise productivity levels within the parameter of sustainability and value addition. This on its turn favors downstream processing of wood. Downstream processing of wood in combination with strict sustainable forest management policy has the tendency to slow down the rate of exploitation of timber (ITTO 2005). Value-added products with strict sustainable forest management policy thus hold the potential to slow down the pressure on tropical forest, and this holds a promising future in terms of sustainability for the timber sector in Ghana.

All environmental inputs (land use, material use and energy) and outputs (emissions and waste) need to be included for identifying options to reduce the burden of Ghana's timber industry on the environment. This study has generated a unique database from tropical forest and the timber industry, which will enhance LCA approaches in Ghana. A full product LCA requires the combination of several units' process LCI data modules and this can be used as regional benchmarks to generate or assess industry, plant or new technology data to develop environmentally oriented decision support system and LCA tools. Having a common set of data based on a single protocol will improve the quality and consistency of LCA's in Africa.

\section{Recommendations and perspectives}

Compiling all inputs and outputs into a transparent inventory for the timber industry in Ghana, provides the industry with overview of areas in which material and thus economic savings can be made for the good of both environment and the industry finances. It also makes it possible to get an overview of whether inputs could be substituted by less polluting materials. This is where life cycle thinking plays a major role in product policy development for a future sustainable industry.

LCI data of good quality and representative for Ghana's timber sector has become available with this study. The next step is to use this LCI data as input for a life cycle 


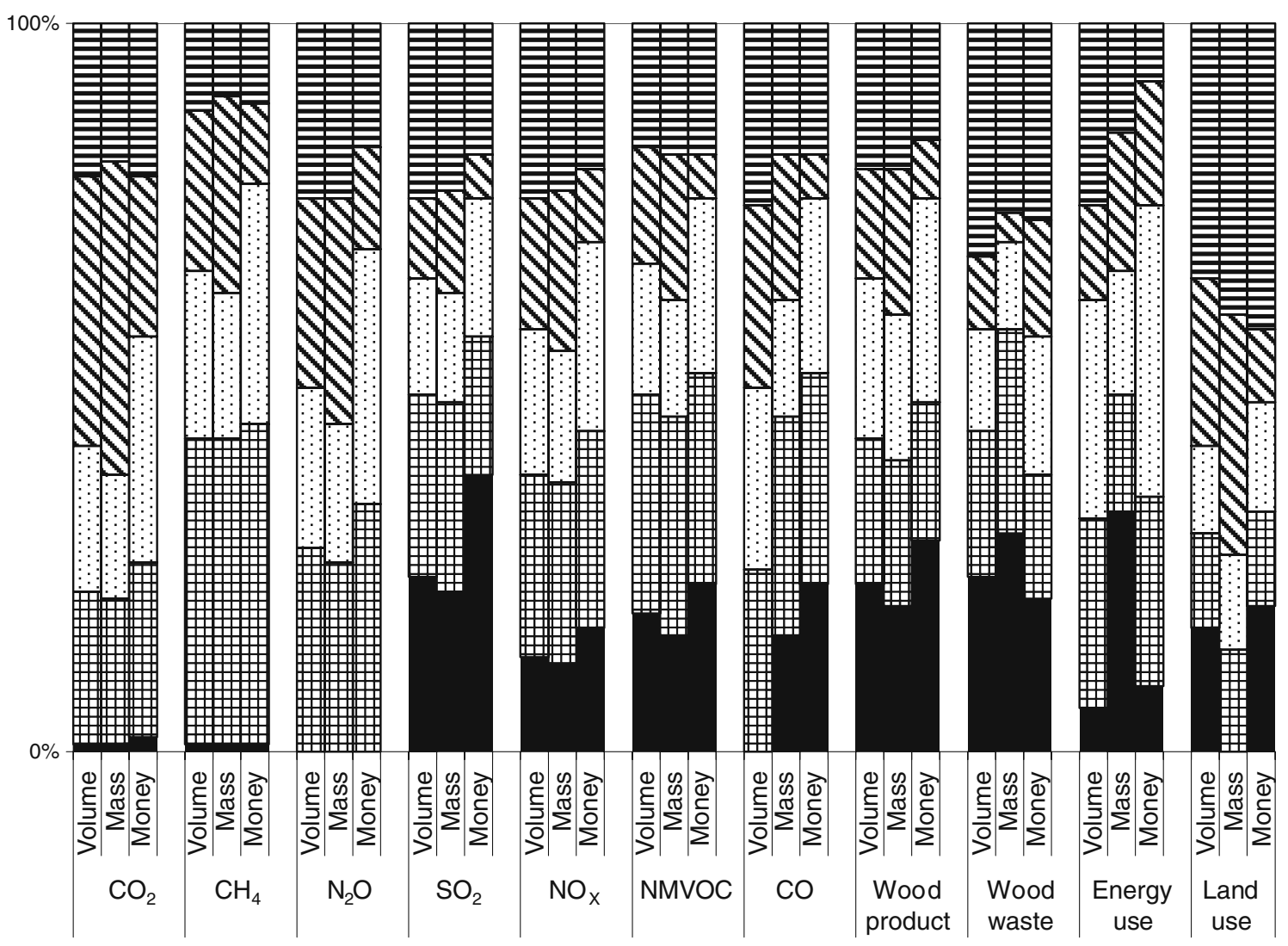

口Furniture Part $\mathbf{\nabla}$ Veneer $\square$ Plywood $\mathbf{\theta}$ Kiln dried lumber $\quad$ Air dried lumber

Fig. 3 Influence of functional unit on LCI results for five major production lines in Ghana's timber sector

impact assessment (LCIA) to identify the environmental impact with the largest relevance for Ghana's timber sector. A comparison and evaluation of existing life cycle methods for this purpose is expected to be finalized and published soon. Results from both LCI and LCIA will be the basis for a detailed improvement assessment as a last step.

Africa is the least known continent in the scientific LCA world, because it has often been a difficult place to do scientific research as a result of limited infrastructure for production inventory data. Good data keeping in the Ghana timber industry will help to build the required research capacity to develop local familiarity and competence in LCA techniques and applying these techniques will help to further certify tropical timber international markets.

Acknowledgment The authors wish to thank the government of Ghana and Wageningen University in the Netherlands for funding the research. We are also grateful to Dr Samuel Obeng Apori (Rector, Takoradi Polytechnic) for their inspiration and assistance during the research work. Last but not least, we like to thank two anonymous referees for their constructive inputs.

Table 6 Summary of results for material consumption and waste production from 2000 to 2007 extrapolated to the average national yearly production of the timber sector in Ghana

\begin{tabular}{|c|c|c|c|c|c|c|c|c|}
\hline & & Units & Air-dried lumber & Kiln-dried lumber & Plywood & Veneer & Furniture parts & Total \\
\hline \multicolumn{9}{|c|}{ Material \& waste } \\
\hline \multirow[t]{3}{*}{ Wood product } & Volume & $\mathrm{mln} \mathrm{m}^{3} /$ year & 0.1 & 0.2 & 0.2 & 0.1 & 0.1 & 0.6 \\
\hline & Mass & ktons/year & 44.0 & 54.0 & 61.0 & 24.0 & 19.0 & 202.0 \\
\hline & Money & mln $€ /$ year & 31.0 & 60.0 & 46.0 & 64.0 & 24.0 & 225.0 \\
\hline \multirow[t]{3}{*}{ Wood waste } & Volume & $\mathrm{mln} \mathrm{m}^{3} /$ year & 0.2 & 0.3 & 0.2 & 0.0 & 0.1 & 0.8 \\
\hline & Mass & ktons/year & 82.0 & 101.0 & 76.0 & 10.0 & 19.0 & 288.0 \\
\hline & Money & mln $€ /$ year & 6.0 & 8.0 & 3.0 & 1.0 & 1.0 & 19.0 \\
\hline
\end{tabular}


Open Access This article is distributed under the terms of the Creative Commons Attribution Noncommercial License which permits any noncommercial use, distribution, and reproduction in any medium, provided the original author(s) and source are credited.

\section{References}

Berg S (1997) Some aspects of LCA in the analysis of forestry operations. J Clean Prod 5:211-217

Erlandsson M, Borg M (2003) Generic LCA-methodology applicable for buildings, constructions and operation services-today practice and development needs. Build Environ 38:919-938

FOSA (2001) Forestry sector outlook studies - FOSA/WP/12. Ministry of Land and forestry, Country report - Ghana

FPIB (1996) Forest product inspection Bureau Ghana. Report unpublished.

Ghana Gazette (2005) A strategic overview of the forest sector in Ghana http://www.lfpdc.lsu.edu-publications-working papers-wp81.pdf

Ghana Gazette (2005) Newsletter about Ghana's forest, timber and wildlife www.ghanatimber.org

Huang C-Y, Shyu JZ, Tzeng G-H (2007) Reconfiguring the innovation policy portfolios for Taiwan's SIP Mall industry. Technovation 27:744

IPCC (1997) Intergovernmental Panel on Climate Change. Third assessment report on climate change 1997. Cambridge: Cambridge University Press

IPCC (2006) Guidelines for GHG- emission. Cambridge: Cambridge University Press

ISO - 14044 (2006) Environmental management-life cycle assessmentrequirements and guidelines

ITTO (2005) International Tropical Timber Organization. Annual review and assessment of the world timber situation,2004.ITTO Yokohama, Japan

Jawjit W, Kroeze C, Soontaranun W, Hordijk L (2006) An analysis of the environmental pressure exerted by the eucalyptus-based kraft pulp industry in Thailand. Environ Dev Sustain 8:289-311

Johnson L, Lippke J, Marshall J, Comnick J (2005) Life-cycle impacts of forest resource activities in the pacific northwest and the Southeast United States. Wood Fiber Sci 37:30-46

Klüppel HJ (1998) ISO 14041: Environmental management-Life Cycle Assessment-Goal and Scope Definition-Inventory Analysis. Int J LCA 3

Lebedys A (2004) Trends and current status of the contribution of the forestry sector to national economies. FAO working paper FSFM/ ACC/07.FAO, Rome, p 138

Lilja R, Liukkonen S (2008) Industrial hazardous wastes in Finlandtrends related to the waste prevention goal. J Clean Prod 16:343

Lippke B, Comnick J, Johnson L (2005) Environmental performance index for the forest. Wood Fiber Sci 37:149-155

Matheys $J$ et al (2007) Influence of functional unit on the life cycle assessment of traction batteries. Int J LCA 12:191-196

Michelsen O (2007) Assessment of land use impact on biodiversity, proposal of a new methodology exemplified with forestry operations in Norway. Int J LCA 13:22-31
Milota MR, West CD, Hartley ID (2005) Gate-to-gate life-cycle inventory of softwood lumber production. Wood Fiber Sci 37:47-57

Nebel B, Zimmer B, Wegener G (2006) Life cycle assessment of wood floor coverings - a representative study for the German flooring industry. Int J LCA 11:172-182

Odoom D (2008) Strategic analysis of Ghana wood export sector. School of renewable natural resources. University of Science and Technology http:etd.Isu.edu/docs/available/etd-04092008143047/unrestricted/Domson thesis.pdf

Oliver R,E Fripp (2005) Changing international markets for timberwhat can African producers do. Producer country draft-Ghana, Timber Trade Federation, UK. pp 4

Ometto AR, Filho AG, Souza MP (2006) Implementation of life cycle thinking in Brazil's Environmental Policy. Environ Sci Policy 9:587

Papatryphon E, Petit J, Kaushik SJ, Hayo MJ (2004) Environmental impact assessment of salmonid feeds using life cycle assessment (LCA). J Hum Environ 33:316-323

Puettmann ME, Wilson JB (2005) Life cycle analysis of wood products (Cradle to gate LCI of residential wood building materials). Wood and Fiber Science: pp 18-22

Rau H, OuYang BC (2008) An optimal batch size for integrated production-inventory policy in a supply chain. Eur J Oper Res $185: 619$

Rivela B, Moreira T, Feijoo G (2007) Life cycle inventory of medium density fibreboard. Int J Life Cycle Assess 12:143-150

Schwaiger H, Zimmer B (1995) A comparison of fuel consumption and greenhouse gas emissions from forest operations in Europe. In: Solberg B, Roihuvo L. (eds.) Environmental impacts of forestry and forest industry. Proceeding of the International Seminar organised by the Finnish-French Society of Science and Technology and the European Forest Institute, Finland

Schweinle J (2007) Wood \& other renewable resources: a challenge for LCA. Int J LCA 12:141-142

Sundkvist A, Finnveden G (2007) Stakeholder needs study on indicators for IPP (Integrated Product Policy). J Clean Prod 15:323

Swarr T (2006) Life cycle management and life cycle thinking: putting a price on sustainability. Int J LCA 11:217-218

TIDD (2006) Timber industry development division (Ghana) technical report http://www.fcghana.com/publications/industrytrade/ export_reports.htm/export_report_main.html.

USEPA (2003) Emission factor documentation for AP-42 Chapter 10, Plywood and composite wood product, United States Environmental Protection Agency (USEPA)

Werner F (2007) life cycle inventories of tropical wood. Life cycle inventories of renewable materials ecoinvent report No. 48, Ecoinvent centre, Dubendorf

Werner F, Nebel B (2007) Wood \& other renewable resources. Int J LCA 12:462-463

Wilson J, Dancer E (2005) Gate-to-gate life-cycle inventory of laminated veneer lumber production. Wood Fiber Sci 37:114127

Wilson J, Sakimoto E (2005) Gate-to-gate life-cycle inventory of softwood plywood production. Wood Fiber Sci 37:58-73

World Bank (2006) World Development Indicators, 2005, The world bank, Washington DC. http://ec.europa.eu-development-icenterrepository-Ghana\%20_CEP_2006.pdf 